Dian S. Kamara, Saadah D. Rachman, Rina Widya Pasisca,Sadiah Djajasoepena, O. Suprijana, Idar Idar, dan Safri Ishmayana Pembuatan dan Akțivitas Antibaß̦teri Yogurt Hasil Fermentasi Tiga Baßteri (Lactobacillus 6ulgaricus, Streptococcus thermophilus, Lactobacilus acidophilus)

\title{
PEMBUATAN DAN AKTIVITAS ANTIBAKTERI YOGURT HASIL FERMENTASI TIGA BAKTERI (Lactobacillus bulgaricus, Streptococcus thermophilus, Lactobacilus acidophilus)
}

\author{
Dian S. Kamara ${ }^{1}$, Saadah D. Rachman ${ }^{2}$, Rina Widya Pasisca ${ }^{1}$, Sadiah \\ Djajasoepena $^{1}$, O. Suprijana ${ }^{1}$, Idar Idar ${ }^{2}$, dan Safri Ishmayana ${ }^{1}$ \\ ${ }^{1}$ Departemen Kimia, Fakultas Matematika dan Ilmu Pengetahuan Alam, \\ Universitas Padjadjaran \\ ${ }^{2}$ Sekolah Tinggi Farmasi Bandung \\ E-mail: ishmayana@unpad.ac.id
}

\begin{abstract}
Exploitation of synthetic antibiotics compounds not only have positive effect for human, but also have side effect that can be unfavorable, therefore many researches are being conducted to find natural antibiotics compounds that are safer. Lactic acid bacteria has the abilitytoproduce antibacterial compound when used in fermentation process. For example, Lactobacillus acidophilus produces acidophilin and acidolin. The main purpose of the present study is to investigate antibacterial activity of yogurt fermented with mixed bacterial culture of L. bulgaricus, S. thermophilus and L. acidophilus against Escherichia coli (representing Gram negative bacteria) and Bacillus subtilis (representing Gram positive bacteria). The antibacterial activity of the yogurt at three different time points $(5,7$ and 9 hours) were examined. We also investigate the fermentation parameters of the yogurt production. The results of the present study indicate that the crude yogurt extract has antibacterial activity, where the highest activity was observed at 7 hour of incubation, resulting 0.35 and $0.30 \mathrm{~cm}$ of clear zone against E. coli and B. subtilis, respectively. It is most likely that the compound is non protein compound.
\end{abstract}

Keywords: antibacterial compound, yogurt, lactic acid bacteria

\section{PENDAHULUAN}

Yogurt merupakan minuman susu terfermentasi yang diketahui memiliki banyak manfaat bagi kesehatan karena adanya aktivitas antimikrobial sehingga dapat mengurangi infeksi gastrointestinal. Selain itu, yoghurt juga memiliki efek antikanker, dapat menurunkan kadar kolesterol dan menstimulasi sistem imun (Shah 2006; Ishmayana dkk. 2015). Karena berbagai efek positif ini, banyak penelitian telah dilakukan baik untuk memperbaiki kualitas produk ataupun mempelajari efek positif yogurt terhadap kesehatan (Allgeyer et al., 2010; Tsoukoulis \& Tzia, 2008; Meyer et al., 2006; Jeon et al., 2007). 
Dian S. Kamara, Saadah D. Rachman, Rina Widya Pasisca,Sadiah Djajasoepena, O. Suprijana, Idar Idar, dan Safri Ishmayana Pembuatan dan Aktivitas Antibakteri Yogurt Hasil Fermentasi Tiga Baßteri (Lactobacillus bulgaricus, Streptococcus thermophilus, Lactobacilus acidophilus)

Yogurt dibuat dari bahan dasar susu yang diinokulasi dengan bakteri asam laktat. Definisi yogurt pada awalnya adalah suatu produk yang dihasilkan dari susu melalui proses fermentasi dengan kultur starter campuran yang terdiri atas S. thermophilus dan L. bulgaricus (Shah, 2006). Namun dalam perkembangannya bakteri asam laktat lain yang sesuai juga dapat ditambahkan ke dalam kultur starter, seperti Lactobacillus acidophilus, Lactobacillus casei, Bifidobacterium lactis dan Bifidobacterium bifidum (Aryana \& McGrew 2007; Ejtahed et al., 2011; Panesar \& Shinje 2012; Rachman et al., 2015). Penambahan bakteri selain $S$. thermophilus dan L. bulgaricus terutama dilakukan karena sifat probiotik kedua bakteri ini kurang baik, sehingga perlu ditambahkan bakteri lain yang memiliki sifat probiotik yang lebih baik, sehingga dapat meningkatkan fungsionalitas dari produk yogurt yang dihasilkan (Gomez \& Malcata 1999).

Kelompok penelitian kami telah menguji aktivitas antibakteri dari produk yogurt yang dibuat dengan menggunakan kultur starter yang mengandung S. thermophilus dan L. bulgaricus (Rachman dkk., 2016). Hasilnya menunjukkan bahwa produk yougurt tersebut berpotensi memiliki aktivitas antibakteri. Penelitian yang juga telah kami lakukan menggunakan tambahan bakteri L. acidophilus pada kultur starter yang menghasilkan kualitas yogurt yang tidak jauh berbeda dengan yogurt yang dibuat dengan kultur starter dua bakteri (Rachman dkk., 2015). Oleh karena itu, pada penelitian ini akan dilakukan penentuan aktivitas antibakteri dari produk yogurt yang dibuat menggunakan kultur tiga bakteri.

\section{METODE PENELITIAN}

\section{Alat}

Alat-alat yang digunakan dalam penelitian ini antara lain adalah termometer, inkubator (Incubig), laminar air flow (Forma Scientific), $\mathrm{pH}$ meter (Mettler Toledo MP-220), Sentrifugasi (Beckman TJ-6 Centrifuge), autoclave dan alat-alat gelas lain yang umum digunakan di laboratorium

\section{Bahan}

Bahan-bahan yang digunakan pada penelitian ini diantaranya adalah agar bakto, bacteriological pepton, yeast extract, glukosa, akuades, asam klorida, biakan $E$. coli dan B. subitilis (diperoleh dari laboratorium mikrobiologi, Departemen Biologi, FMIPA, Unpad), biakan murni $L$. bulgaricus, S. thermophilus, dan L. acidophilus (diperoleh dari Laboratorium 
Dian S. Kamara, Saadah D. Rachman, Rina Widya Pasisca,Sadiah Djajasoepena, O. Suprijana, Idar Idar, dan Safri Ishmayana Pembuatan dan Akttivitas Antibakțeri Yogurt Hasil Fermentasi Tiga Baktteri (Lactobacillus 6ulgaricus, Streptococcus thermophilus, Lactobacilus acidophilus)

Mikrobiologi, Institut Teknologi Bandung), susu skim, dan susu sapi murni yang diperoleh dari Fakultas Peternakan, Unpad.

\section{Prosedur Kerja}

\section{Pembuatan Media Cair Susu Skim}

Media cair susu skim $10 \%$ b/v dibuat dengan cara sebanyak 5 gram susu skim ditimbang dan dilarutkan dalam $50 \mathrm{~mL}$ akuades kemudian dipanaskan dan diaduk sampai larut sampai mencapai $85^{\circ} \mathrm{C}$ selama 10 menit

\section{Pembuatan Media Agar Pepton-Yeast-Glukosa (PYG)}

Sebanyak $0,25 \mathrm{~g}$ pepton, $0,05 \mathrm{~g}$ glukosa, $0,125 \mathrm{~g}$ yeast extract dan $0,9 \mathrm{~g}$ agar bakto ditimbang dan dilarutkan dalam $50 \mathrm{~mL}$ akuades. Larutan kemudian didihkan dan diaduk sampai benar-benar larut kemudian diautoclave.

\section{Pembuatan Kultur Starter Tunggal}

Sebanyak tiga labu Erlenmeyer yang telah disterilkan disiapkan dan ke dalamnya dimasukkan $10 \mathrm{~mL}$ media cair susu skim $10 \% \mathrm{~b} / \mathrm{v}$ yang telah dipasteuriasi pada suhu $85^{\circ} \mathrm{C}$ selama 10 menit dan didiamkan sampai dengan suhu $40^{\circ} \mathrm{C}$. Kemudian ke dalam masing-masing labu Erlenmeyer dimasukkan satu mata ose L. bulgaricus, S. thermophilus, dan L. acidophilus lalu dikocok perlahan. Kultur tersebut diinkubasi selama 24 jam pada suhu $40^{\circ} \mathrm{C}$ dan selanjutnya disimpan di lemari es.

\section{Pembuatan Kultur Starter Campuran}

Pada tahap ini dibuat kultur starter campuran L. bulgaricus, S. thermophilus dan L. acidophilus $=1: 1: 1=\mathrm{v}: \mathrm{v}: \mathrm{v}$. Sebanyak $150 \mathrm{~mL}$ susu skim yang akan difermentasi dipasterisasi pada suhu $85^{\circ} \mathrm{C}$ selama 10 menit, kemudian dimasukkan sebanyak $5 \mathrm{~mL}$ kultur starter L. bulgaricus, $5 \mathrm{~mL}$ kultur starter $S$. thermomphilus dan $5 \mathrm{~mL}$ kultur starter L. acidophilus lalu dikocok perlahan. Kultur tersebut diinkubasi selama 24 jam pada suhu $40^{\circ} \mathrm{C}$ dan selanjutnya disimpan di lemari es.

\section{Pembuatan Kurva Baku Pertumbuhan Kultur Tunggal}

Ke dalam 3 buah labu Erlenmeyer yang sudah diisi dengan $100 \mathrm{~mL}$ media cair susu skim masing-masing diinokulasi dengan $10 \mathrm{~mL}$ kultur starter tunggal. Kemudian dilakukan inkubasi pada suhu $40^{\circ} \mathrm{C}$ dan setiap 2 jam diukur densitas optiknya pada panjang gelombang $600 \mathrm{~nm}$. 
Dian S. Kamara, Saadah D. Rachman, Rina Widya Pasisca,Sadiah Djajasoepena, O. Suprijana, Idar Idar, dan Safri Ishmayana Pembuatan dan Aßțtivitas Antibaßteri Yogurt Hasil Fermentasi Tiga Baßteri (Lactobacillus 6ulgaricus, Streptococcus thermophilus, Lactobacilus acidophilus)

\section{Pembuatan Kurva Pertumbuhan Gabungan Tiga Bakteri}

Ke dalam sebuah labu Erlenmeyer yang sudah diisi dengan $100 \mathrm{~mL}$ media cair susu skim ditambahkan kultur starter campuran sebanyak $10 \mathrm{~mL}$. Kemudian dilakukan inkubasi pada suhu $40^{\circ} \mathrm{C}$ dan setiap 2 jam diukur densitas optiknya pada panjang gelombang $600 \mathrm{~nm}$.

\section{Pembuatan Yogurt}

Susu murni yang akan difermentasi dipasteurisasi terlebih dahulu dengan pemanasan pada suhu $85^{\circ} \mathrm{C}$ selama 10 menit. Kemudian ditambahkan kultur starter campuran lalu dikocok dan diinkubasi pada suhu $40^{\circ} \mathrm{C}$ selama 5,7 dan 9 jam.

\section{Ekstraksi Senyawa Antibakteri dari Yogurt}

Yogurt disentrifugasi pada suhu $4^{\circ} \mathrm{C}$ dengan kecepatan $5000 \mathrm{rpm}$ selama 15 menit. Supernatan yang terbentuk diberi etanol dingin $\left(10^{\circ} \mathrm{C}\right)$ dengan perbandingan 1:1 dan disimpan pada suhu $10^{\circ} \mathrm{C}$ selama 24 jam. Selanjutnya disentrifugasi kembali dengan kecepatan 5000 rpm selama 15 menit. Supernatan yang terbentuk dipekatkan dengan rotary vacuum evaporator dengan pemanasan $55^{\circ} \mathrm{C}$ sampai pekat. Ekstrak yang diperoleh diencerkan dengan air sampai volumenya mencapai $1 / 5$ volume awal. Larutan ini siap untuk diuji aktivitas antibakterinya.

\section{Uji Aktivitas Senyawa Antibakteri}

Sebanyak dua cawan petri berdiameter $10 \mathrm{~cm}$ disterilkan dan ke dalamnya masing-masing ditambahkan dengan $20 \mathrm{~mL}$ media agar PYG yang belum memadat dan masing-masing telah ditambahkan dengan $0,1 \mathrm{~mL}$ inokulum B. subtilis dan E. coli kemudian dituangkan ke dalam cawan petri. Kemudian dikocok dan dibiarkan sampai memadat. Pada media agar yang telah memadat, diberi lubang dengan diameter $6 \mathrm{~mm}$. Sebanyak $20 \mu \mathrm{L}$ ekstrak yang akan diuji diteteskan ke dalam lubang, kemudian diinkubasi pada suhu $37^{\circ} \mathrm{C}$ selama 24 jam. Setelah inkubasi selesai, diamati daerah bening yang menunjukkan adanya hambatan pertumbuhan bakteri kemudian diukur diameternya.

\section{HASIL DAN PEMBAHASAN}

\section{Kurva Pertumbuhan}

Kurva pertumbuhan dibuat untuk menentukan fase yang terjadi selama proses fermentasi. Hasil pengukuran kurva pertumbuhan ditunjukkan pada Gambar 1. Hasil pada Gambar 1 menunjukkan bahwa terjadi fase adaptasi atau 
Dian S. Kamara, Saadah D. Rachman, Rina Widya Pasisca,Sadiah Djajasoepena, O. Suprijana, Idar Idar, dan Safri Ishmayana Pembuatan dan Aktivitas Antibakteri Yogurt Hasil Fermentasi Tiga Bakteri (Lactobacillus bulgaricus, Streptococcus thermophilus, Lactobacilus acidophilus)

lag pada jam ke-0 sampai ke-2 baik untuk kultur bakteri tunggal ataupun campuran. Fase eksponensial atau log untuk S. thermophilus dan L. bulgaricus terjadi pada jam ke-2 sampai dengan jam ke-6, sedangkan untuk L. acidophilus dan kultur campuran tiga bakteri terjadi pada jam ke-2 sampai ke-8. Fase eksponensial kemudian diikuti oleh fase stasioner yang berakhir pada jam ke10, kecuali untuk kultur campuran yang berakhir pada jam ke-12. Setelah itu, diikuti oleh fase kematian.

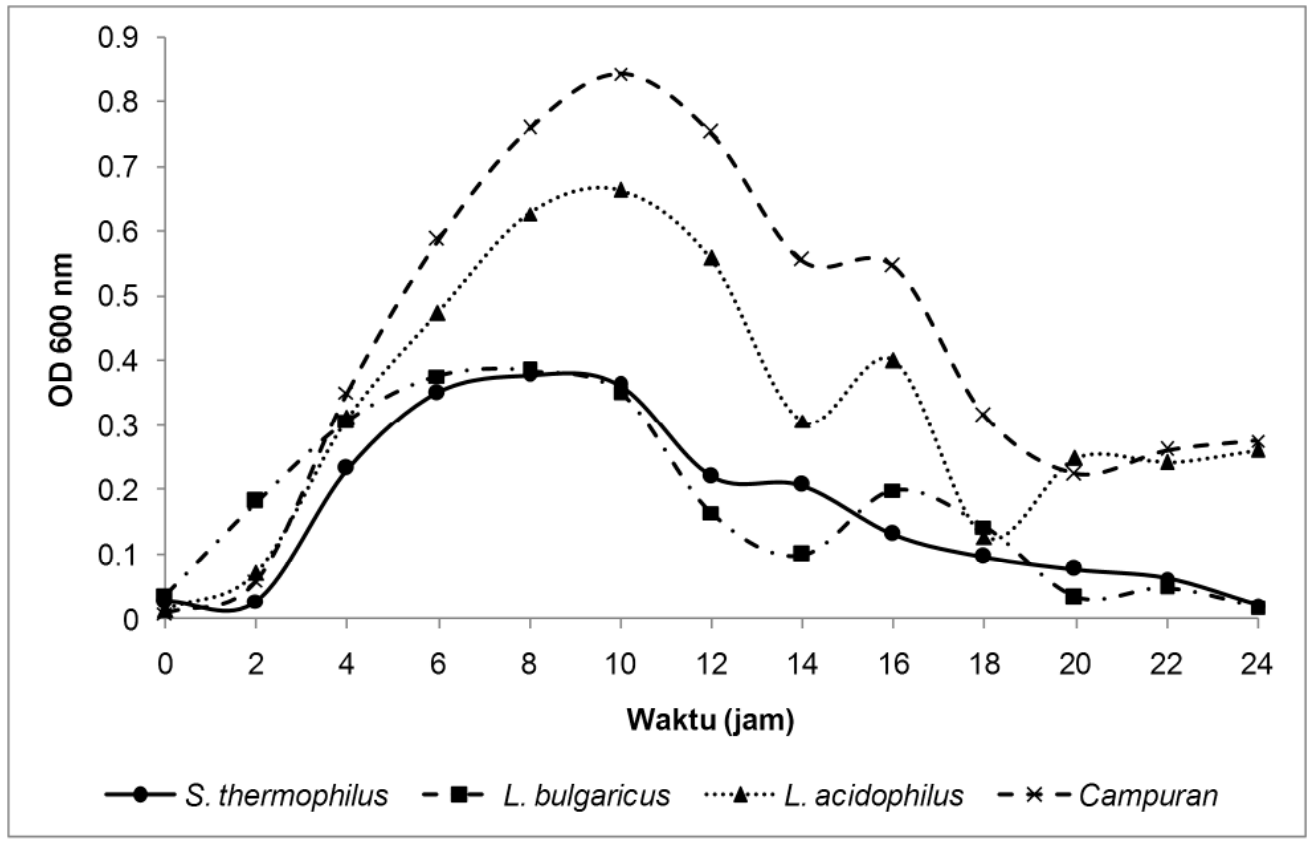

Gambar 1.Kurva Pertumbuhan Bakteri S. thermophilus, L. bulgaricus, L. acidophilus dan Campuran Ketiga Bakteri dengan Perbandingan 1:1:1 = v:v:v pada Media Susu Skim 10\% b/v. Kultur Diinkubasi selama 24 Jam pada Suhu $40^{\circ} \mathrm{C}$

Fase stasioner untuk S. thermophilusdan L. bulgaricus terlihat lebih jelas dibandingkan dengan fase stasioner L. acidophilus dan kultur campuran. Bakteri L. acidophilus tampaknya memiliki daya tumbuh yang lebih baik dibandingkan dengan bakteri lainnya. Pada kultur campuran pun terlihat terjadi pertumbuhan yang lebih tinggi dibandingkan kultur tunggal, yang kemungkinan besar dipengaruhui oleh adanya bakteri L. acidophilus yang ada dalam kultur campuran. Temuan ini sejalan dengan Chick et al. (2001), yang melaporkan bahwa pada media yang sama, L. acidophilus mencapai jumlah sel yang lebih 
Dian S. Kamara, Saadah D. Rachman, Rina Widya Pasisca,Sadiah Djajasoepena, O. Suprijana, Idar Idar, dan Safri Ishmayana Pembuatan dan Aktivitas Antibakteri Yogurt Hasil Fermentasi Tiga Bakteri (Lactobacillus bulgaricus, Streptococcus thermophilus, Lactobacilus acidophilus)

banyak dibandingkan S. thermophilus, L. bulgaricus dan Bifidobacterium bifidum.

\section{Kultur Starter Tunggal dan Campuran}

Pembuatan kultur starter bertujuan untuk membantu proses adaptasi bakteri, sehingga ketika proses fermentasi dimulai fase adaptasi dalam media fermentasi menjadi lebih cepat. Media yang digunakan untuk membuat kultur starter adalah susu skim, karena kandungan susu skim lebih stabil dibandingkan susu murni sehingga akan lebih terjaga konsistensi hasil serta lebih mudah bagi bakteri untuk beradaptasi.

Dengan mengamati penurunan nilai $\mathrm{pH}$ media susu skim $10 \% \mathrm{~b} / \mathrm{v}$ yang telah diinokulasi dengan bakteri asam laktat, maka dapat diketahui bahwa bakteri tersebut aktif, yang ditandai dengan kemampuannya untuk mengubah laktosa menjadi asam laktat sehingga menyebabkan turunnya nilai $\mathrm{pH}$. Hasil pengukuran $\mathrm{pH}$ susu skim $10 \% \mathrm{~b} / \mathrm{v}$ dan produk hasil inkubasi ditunjukkan pada Tabel 1. Nilai $\mathrm{pH}$ susu skim $10 \% \mathrm{~b} / \mathrm{v}$ adalah sebesar 6,92 . Setelah diinkubasi selama 24 jam, pH turun menjadi 4,37; 4,37; 4,41 dan 4,34 masing-masing untuk susu skim yang difermentasi dengan L. bulgaricus, S. thermophilus, L. acidophilus dan campuran ketiga bakteri dengan perbandingan 1:1:1 = v:v:v. Berdasarkan nilai $\mathrm{pH}$ yang diukur, maka kesemua kultur starter memenuhi criteria kultur starter yang baik, dimana menurut Marshall (1987) kultur starter yang baik memiliki nilai pH pada rentang 3,8-4,6.

Tabel 1. Nilai pH Media Cair Susu Skim $10 \%$ b/v dan Kultur Starter Hasil Inkubasi Selama 24 Jam

\begin{tabular}{ll}
\hline Sampel & pH \\
\hline Susu skim 10\% b/v & 6,92 \\
Kultur starter dengan L. bulgaricus & 4,37 \\
Kultur starter dengan S. thermophiles & 4,37 \\
Kultur starter dengan L. acidophilus & 4,41 \\
Kultur starter dengan campuran bakteri & 4,34 \\
\hline
\end{tabular}

\section{Pembuatan Yogurt}

Pada penelitian ini, yogurt dibuat dengan menggunakan kultur starter campuran tiga bakteri. Salah satu faktor yang mempengaruhi kualitas yogurt adalah lama waktu inkubasi. Semakin lama waktu inkubasi, maka akan semakin banyak asam laktat yang diproduksi, sehingga nilai $\mathrm{pH}$ pun menjadi 
Dian S. Kamara, Saadah D. Rachman, Rina Widya Pasisca,Sadiah Djajasoepena, O. Suprijana, Idar Idar, dan Safri Ishmayana Pembuatan dan Aktivitas Antibakteri Yogurt Hasil Fermentasi Tiga Baßteri (Lactobacillus bulgaricus, Streptococcus thermophilus, Lactobacilus acidophilus)

semakin rendah. Hasil pengukuran $\mathrm{pH}$ pada berbagai waktu inkubasi ditunjukkan pada Tabel 2.

Tabel 2. Nilai pH Yogurt dengan Variasi Waktu Inkubasi. Yogurt dibuat dengan Menggunakan Kultur Starter Campuran Tiga Bakteri (L. bulgaricus, $S$. thermophilus dan L. acidophilus dengan Perbandingan 1:1:1 = v:v:v) dan Diinkubasi pada Suhu $40^{\circ} \mathrm{C}$

\begin{tabular}{cl}
\hline Waktu inkubasi (jam) & Ph \\
\hline 5 & 5,00 \\
7 & 4,70 \\
9 & 4,50 \\
\hline
\end{tabular}

Hasil pengukuran $\mathrm{pH}$ menunjukkan bahwa yogurt yang baik diperoleh pada jam ke-9, karena menurut Food Standards Australia New Zealand (2014) yogurt yang baik memiliki nilai $\mathrm{pH}$ maksimum 4,5. Waktu inkubasi yang digunakan didasarkan pada kurva pertumbuhan yang telah ditentukan sebelumnya, dimana fase eksponensial kultur bakteri campuran terjadi pada jam ke-2 sampai ke-8. Sehingga pada penelitian ini inkubasi dihentikan setelah inkubasi selama 9 jam agar proses fermentasi dihentikan masih pada fase eksponensial, pada akhir fase eksponensial atau mulai memasuki fase stasioner.

\section{Uji Aktivitas Antibakteri}

Ekstrak kasar yang diperoleh diuji terhadap dua bakteri, yaitu E. coli yang mewakili bakteri gram negatif dan B. subtilis yang mewakili bakteri gram positif. Metode yang digunakan adalah metode perforasi. Hasil uji bakteri ditunjukkan pada Gambar 3 dan Gambar 4, sedangkan hasil pengukuran zona bening ditunjukkan pada Tabel 3.

Seperti yang ditunjukkan pada Tabel 3 dan Gambar 2, diameter zona bening yang dihasilkan oleh senyawa antibakteri yang diperoleh dari ekstrak yogurt terhadap E. coli relatif lebih besar dibandingkan diameter zona bening terhadap B. subtilis. Hal ini menunjukkan bahwa senyawa yang diekstrak dari yogurt memiliki daya hambat yang lebih baik terhadap bakteri gram negatif. Beberapa penelitian kelompok lain melaporkan adanya aktivitas antibakteri dari produk yogurt yang kemungkinan besar disebabkan adanya kemampuan bakteri asam laktat untuk menghasilkan protein kecil yang disebut sebagai bacteriosin (Chuayana et al., 2003; Goraya et al., 2013). Selain itu ada juga senyawa antibakteri lainnya yang juga dihasilkan oleh kelompok bakteri asam laktat, yaitu reuterin (Arqués et al., 2004). Karena proses isolasi pada penelitian ini 
Dian S. Kamara, Saadah D. Rachman, Rina Widya Pasisca,Sadiah Djajasoepena, O. Suprijana, Idar Idar, dan Safri Ishmayana Pembuatan dan Akțivitas Antibaß̦teri Yogurt Hasil Fermentasi Tiga Baßteri (Lactobacillus 6ulgaricus, Streptococcus thermophilus, Lactobacilus acidophilus)

yang menggunakan etanol dan pemanasan, maka kemungkinan besar senyawa yang telah diisolasi adalah senyawa antibakteri seperti kelompok reuterin.

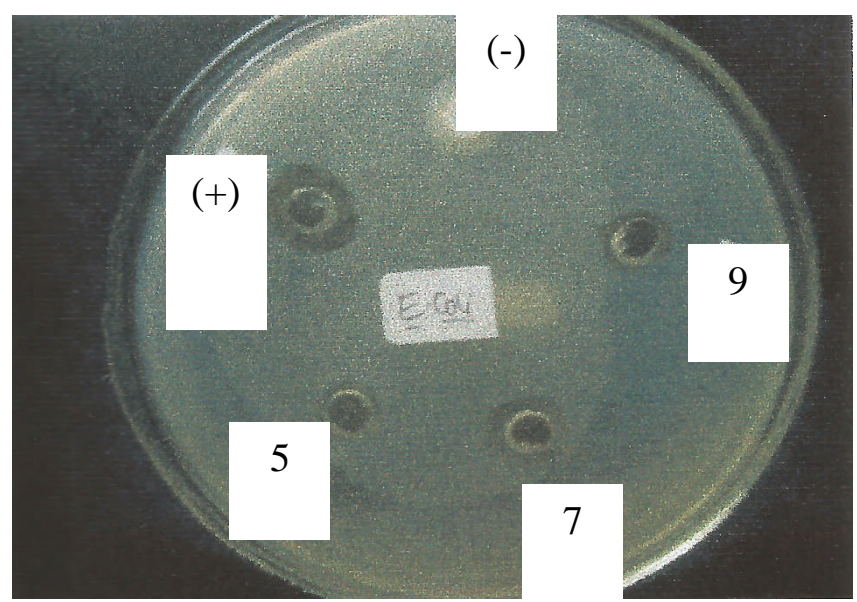

Gambar 3. Uji Aktivitas Antibakteri Ekstrak Kasar Yogurt terhadap E. coli. (+) Kontrol Positif (Amoksisilin $1 \mathrm{mg} / \mathrm{mL}$ ); (-) Kontrol Negatif (Susu Murni); 5, 7 dan 9 masing-masing adalah Ekstrak Yogurt yang Diinkubasi selama 5, 7 dan 9 Jam

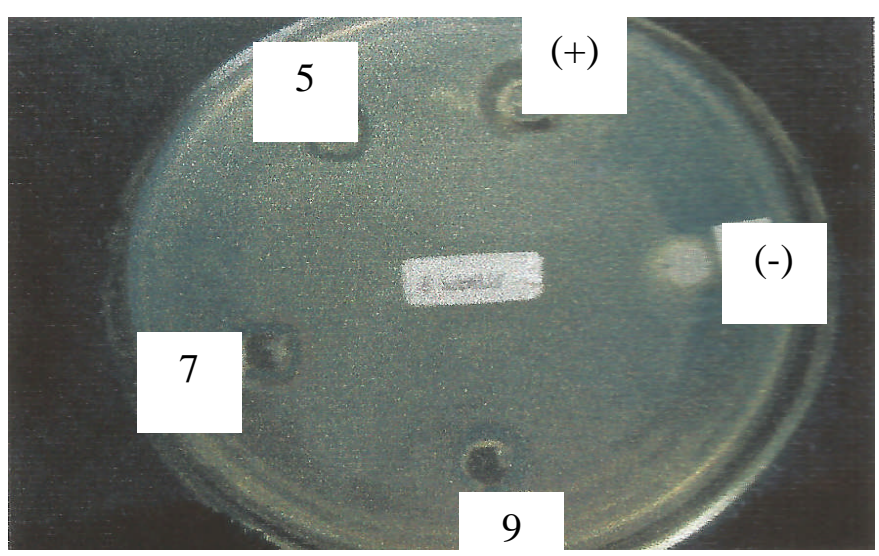

Gambar 4. Uji Aktivitas Antibakteri Ekstrak Kasar Yogurt terhadap B. subtilis. (+) Kontrol Positif (Amoksisilin $1 \mathrm{mg} / \mathrm{mL}$ ); (-) Kontrol Negatif (Susu Murni); 5, 7 dan 9 masing-masing adalah Ekstrak Yogurt Yang Diinkubasi selama 5, 7 dan 9 Jam 
Dian S. Kamara, Saadah D. Rachman, Rina Widya Pasisca,Sadiah Djajasoepena, O. Suprijana, Idar Idar, dan Safri Ishmayana Pembuatan dan Aktivitas Antibakteri Yogurt Hasil Fermentasi Tiga Baßteri (Lactobacillus bulgaricus, Streptococcus thermophilus, Lactobacilus acidophilus)

Tabel 3. Data Diameter Zona Bening (dalam Satuan cm) Hasil Uji Bakteri Ekstrak Kasar Senyawa yang Diisolasi dari Yogurt terhadap E. coli dan B. subtilis

\begin{tabular}{lll}
\hline \multirow{2}{*}{ Sampel } & \multicolumn{2}{c}{ Bakteri Uji } \\
\cline { 2 - 3 } & E. coli & B. subtilis \\
\hline Kontrol negatif & - & - \\
Kontrol positif (amoksisilin 10 mg/mL) & 0,50 & 0,50 \\
Yogurt waktu inkubasi 5 jam & 0,10 & 0,10 \\
Yogurt waktu inkubasi 7 jam & 0,35 & 0,30 \\
Yogurt waktu inkubasi 9 jam & 0,30 & 0,20 \\
\hline
\end{tabular}

Keterangan: - = tidak ada zona hambat

Selain itu, waktu inkubasi juga mempengaruhi aktivitas antibakteri. Seperti ditunjukkan pada Tabel 3, yogurt yang diinkubasi selama 7 jam memiliki aktivitas paling tinggi. Pada jam ke-9, aktivitas antibakteri menurun. Hal ini dimungkinkan terjadi karena adanya proses degradasi senyawa antibakteri oleh aktivitas dari bakteri itu sendiri, sehingga daya hambat pada jam ke-9 menjadi menurun.

\section{PENUTUP}

\section{Kesimpulan}

Yogurt yang dibuat dengan menggunakan kultur campuran tiga bakteri memiliki aktivitas antibakteri. Hasil uji antibakteri yogurt tiga bakteri menunjukkan bahwa aktivitas antibakteri tertinggi dicapai pada jam ke-7 dengan diameter zona hambat sebesar 0,35 dan 0,3 masing-masing untuk E. coli dan B. subtilis. Dari hasil ini dapat disimpulkan bahwa senyawa pada yogurt memiliki daya hambat yang lebih besar terhadap bakteri gram negatif.

\section{Saran}

Untuk penelitian lebih lanjut disarankan untuk melakukan pemurnian terhadap senyawa antibakteri yang terdapat dalam ekstrak yogurt tersebut dan melakukan penentuan struktur dari senyawa aktifnya sehingga mekanisme inhibisinya dapat lebih dipahami. 
Dian S. Kamara, Saadah D. Rachman, Rina Widya Pasisca,Sadiah Djajasoepena, O. Suprijana, Idar Idar, dan Safri Ishmayana Pembuatan dan Akțivitas Antibakțeri Yogurt Hasil Fermentasi Tiga Bakteri (Lactobacillus bulgaricus, Streptococcus thermophilus, Lactobacilus acidophilus)

\section{DAFTAR PUSTAKA}

Allgeyer, L.C., Miller, M.J.,and Lee, SY., 2010, Sensory and microbiological quality of yogurt drinks with prebiotics and probiotics,Journal of Dairy Science, 93(10): 4471-4479.

Arqués, J.L., Fernández, J., Gaya, P., Nuñez, M., Rodríguez, E., and Medina, M., 2004, Antimicrobial activity of reuterin in combination with nisin against food-borne pathogens, International Journal of Food Microbiology, 95(2): 225-229.

Chick, H., Shin, H.S., and Ustunol, Z., 2001, Growth and Acid Production by Lactic Acid Bacteria and Bifidobacteria Grown in Skim Milk Containing Honey, Journal of Food Science, 66(3): 478-481.

Chuayana Jr., E.L., Ponce, C.V., Rivera, M.R.B., and Cabrera, E.C., 2003, Antimicrobial Activity of Probiotics from Milk Products, Philippine Journal of Microbiology and Infectious Diseases, 32(2): 71-74.

Food Standards Australia New Zealand, 2014,Standard 2.5.3 Fermented milk products.

Gomes, A.M.P., Malcata, F.X., 1999, Bifidobacterium spp. and Lactobacillus acidophilus: biological, biochemical, technological and therapeutical properties relevant for use as probiotics, Trends in Food Science \& Technology, 10(4): 139-157.

Goraya, M., Ashraf, U.M., Ur-Rahman, S., Raza, A.,and Habib, A., 2013, Determination of antibacterial activity of bacteriocins of lactic acid producing bacteria, Journal of Infection and Molecular Biology, 1: 1-7.

Ishmayana, S., Juanda, A., Suprijana, O., Djajasoepena, S., Idar, I.,dan Rachman, S.D., 2015, Pengaruh Konsumsi Yogurt Yang Dibuat Dengan Kultur Dua Bakteri (Sterptococcus thermophillus dan Lactobacillus bulgaricus) dan Tiga Bakteri (Sterptococcus thermophillus, Lactobacillus bulgaricus dan Lactobacillus acidophilus) Terhadap Kadar Kolesterol Seru, Chimica et Natura Acta, 3(3): 94-99.

Jeon, J.-R., Kim, J.-Y., and Choi, J.-H., 2007, Effect of Yam Yogurt on Colon Mucosal Tissue of Rats with Loperamide-induced Constipation,FoodScience and Biotechnology, 16(4): 605-609.

Meyer, A.L., Micksche, M., Herbacek, I.,and Elmadfa, I., 2006, Daily Intake of Probiotic as well as Conventional Yogurt Has a Stimulating Effect on Cellular Immunity in Young Healthy Women,Annals of Nutrition and Metabolism, 50(3): 282-289.

Rachman, S.D., Djajasoepena, S., Indrawati, I., Bangun, L., Kamara, D.S. dan Ishmayana, S., 2016, Penentuan Kadar Riboflavin dan Uji Pendahuluan Aktivitas Antibakteri Yogurt yang Difermentasi dengan Bakteri yang 
Dian S. Kamara, Saadah D. Rachman, Rina Widya Pasisca,Sadiah Djajasoepena, O. Suprijana, Idar Idar, dan Safri Ishmayana Streptococcus thermophilus, Lactobacilus acidophilus

Diisolasi dari Yogurt Komersial, Seminar Nasional Kimia dan Pembelajaran Kimia, Departemen Kimia, Universitas Padjadjaran, Jatinangor. 12 Mei 2016

Rachman, S.D., Djajasoepena, S., Kamara, D.S., Idar, I., Sutrisna, R., Safari, A., Suprijana, O., dan Ishmayana, S., 2015, Kualitas Yoghurt yang Dibuat Dengan Kultur Dua (Lactobacillus bulgaricus dan Streptococcus thermophilus) dan Tiga Bakteri (Lactobacillus bulgaricus, Streptococcus thermophilus dan Lactobacillus acidophilus), Chimica et Natura Acta, 3(2): 76-79.

Shah, N.P., 2006, Health Benefit of Yogurt and Fermented Milks, in R.C. Chandan, C.H. White, A. Kilara, Y.H. Hui (eds.), Manufacturing Yogurt and Fermented Milks, Oxford: Blackwell Publishing.

Soukoulis, C., Tzia, C., 2008, Impact of the acidification process, hydrocolloids and protein fortifiers on the physical and sensory properties of frozen yogurt, International Journal of Dairy Technology, 61(2): 170-177. 